\title{
The fundamental right to property and the protection of investment: How difficult is it to repeal new intellectual property rights?
}

forthcoming in Christophe Geiger (eds), Research Handbook on Intellectual Property and Investment Law (Edward Elgar 2019)

Martin Husovec ${ }^{1}$

\section{INTRODUCTION}

In the 2010s, we are witnessing a number of policy debates concerning proposals for new intellectual property rights. The high-profile examples include publishers' rights, data producers' rights and sport events organizers' rights. The arguments behind these rights are purely utilitarian, unlike in the case of some traditional intellectual property rights, such as authors' or inventors' rights. These rights are clearly presented as tools of European Union (EU) innovation policy, incentivizing quality journalism, data creation and trading or investments in sports. However, how sticky are these tools?

\footnotetext{
${ }^{1}$ I would like to thank Christophe Geiger, Jonathan Griffiths, Bernt Hugenholtz, Martin Kretschmer, Daniël Jongsma, Alexander Peukert and Caterina Sganga for their debates and/or comments related to this work.
} 
A lot of attention in the literature rightly focuses on the first-order issue of their social costs and benefits. Little attention is paid to the problem of institutional inertia which keeps some of these solutions in circulation despite their proven ineffectiveness. While economic progress is unthinkable without stable property rights, it is equally unthinkable without their never-ending adjustment and continuous reflection of their effects. ${ }^{2}$ In this article, I pose the following question: how difficult is it to legislate away a new set of intellectual property rights once they are found to be incapable of delivering on their promises?

In his recent contribution, Geiger asks essentially the same question, though from what at first appears as an entirely different perspective. He wonders whether the EU will still be able to regulate intellectual property rights freely, given the increasing reliance on investment protection anchored in international treaties. ${ }^{3}$ In my contribution, I explore the question of regulatory autonomy by looking at the guarantees offered by Article 17 of the EU Charter. Initially, the two issues might appear separated by a brick wall. Investment protection usually presents itself as containing its own sets of rules and mechanisms which apply autonomously as an additional layer of protection granted to investors. ${ }^{4}$ Unlike protection by fundamental rights, it is litigated before private tribunals and not courts.

\footnotetext{
2 Drahos refers to this as a 'property paradox' - see Peter Drahos, 'Intellectual Property and Human Rights' (1999) 3 Intellectual Property Quarterly 349.

3 Christopher Geiger, 'The TTIP and Its Investment Protection: Will the EU Still Be Able to Regulate Intellectual Property?' (2018) 49 (6) IIC - International Review of Intellectual Property and Competition Law 631.

${ }^{4}$ Henning Grosse Ruse-Khan, 'Investment Law and Intellectual Property Rights' in Marc Bungenberg et al. (eds.), International Investment Law: A Handbook (C.H. Beck/Hart/Nomos, 2015), 1741.
} 
However, as noted by Gervais, '[t]he triangular interface between trade, intellectual property (IP) and human rights has yet to be fully formed, both doctrinally and normatively'. 5 In fact, the empirical analysis of Alvarez shows that if (European Court of Human Rights) ECHR case-law is discussed, despite its uncertain doctrinal status, it is in fact cited as often by investor claimants as respondent states. ${ }^{6}$ In the past, respondents states for instance referred to (European Court of Human Rights) ECtHR case-law concerning expropriation and fair compensation. ${ }^{7}$ Claimants have invoked it in order to extend the findings of domestic constitutional courts, declaring the violation of a fundamental right to property under the ECHR, to their investment disputes. ${ }^{8}$ Similarly, EU law dictated outcomes interfering with the property of investors in Member States were scrutinized through investment protection. ${ }^{9}$ Therefore these two lines of enquiries cannot be presented as being entirely disconnected and although the brick wall exists, it has more windows than one might think. As explained by Alvarez, 'international investment agreements are, at least as deployed by some investor claimants, human rights treaties for a special kind of "human"-namely foreigners armed

${ }^{5}$ Daniel Gervais, 'Investor-State Dispute Settlement: Human Rights and Regulatory Lessons from Lilly v. Canada’ (2018) 8 UC Irvine Law Review 459.

6 See Jose A. Alvarez, 'The Use (and Misuse) of European Human Rights Law in Investor-State Dispute Settlement', in Franco Ferarri (ed.) The Impact of EU Law on International Commercial Arbitration (Juris 2017) 523.

${ }^{7}$ Siemens A.G. v. Argentine Republic, ICSID Case No. ARB/02/8, Award (Feb. 6, 2007); Quiborax v. Bolivia, ICSID Case No. ARB/06/2, Decison (Sept. 16, 2015); Bernhard von Pezold and others v. Republic of Zimbabwe, ICSID Case No. ARB/10/15, Decision (July 28, 2015).

${ }^{8}$ European American Investment Bank AG (EURAM) v. Slovak Republic, PCA Case No. 2010-17, Decison (June 4, 2014).

${ }^{9}$ Electrabel S.A. v Republic of Hungary, ICSID Case No. ARB/07/19, Decision (Nov. 30, 2012). 
with capital'. ${ }^{10}$ It is therefore no coincidence that the dimension of Article 17(2) might play a role in the system, even if only of an argumentative and reflective nature.

Therefore, this contribution takes a broader approach towards the notion of 'investment protection'. It scrutinizes how protection granted to investments through IP rights is subsequently constraining the legislator because of the set of constitutional safeguards. The fundamental right to property is thus used as a lens for the analysis of the theoretical and actual maneuvering space left to democratically elected parliaments should they decide to abridge, redesign or repeal IP rights. Special attention is paid to the European federal setting which creates a unique set of challenges in this respect.

\section{EUROPEAN STATUS QUO INERTIA}

All intellectual property rights exist for a reason. However, they all have a different legislative purpose. Apart from justice arguments applicable to a few IP rights, ${ }^{11}$ the exclusive rights are mostly about optimal incentives for innovation, investment and diffusion. ${ }^{12}$ In theory, the legislator's choices should be continuously challenged against the

10 Jose A. Alvarez, 'The Use (and Misuse) of European Human Rights Law in Investor-State Dispute Settlement', in Franco Ferarri (ed.) The Impact of EU Law on International Commercial Arbitration (Juris 2017) 520 .

${ }^{11}$ See CJEU, C-469/17, Funke Medien [2019], Opinion of Advocate General Szpunar, para 58 (discussing dual objectives of copyright protection for authors).

12 Although the EU legislation and case-law of the CJEU usually (from the utilitarian side) emphasized only the dimension of optimal incentives for investment (see for example, CJEU, C-469/17, Funke Medien [2019], Opinion of Advocate General Szpunar, para 58; CJEU, Case C-476/17, Pelham GmbH, Moses Pelham, Martin Haas v Ralf Hütter, Florian Schneider-Esleben [2018], Opinion of the Advocate General Szpunar, paras 83, 
background of this purpose, thereby reviewing their actual performance. However, legislative challenges of IP rights are extremely rare. ${ }^{13}$ The historical trajectory of intellectual property law in the last century has been to simply keep adding new rights whenever there is a major technological change. The same legislator almost never goes back to question its old choices. These old choices simply stick, even if original industries vanish or technological realities change completely. This makes IP rights a very heavy- handed tool of innovation policy. Not because of the technique of exclusive rights, but due to political economy that fails to challenge ineffective tools. With the passing of time, some choices become so 'obvious' that they start to be perceived as natural entitlements - 'good old property rights' ${ }^{\prime 4}$. Such rights are then practically immune to evidence in the political

84; Recital 1 of the Directive 2004/48/EC of the European Parliament and of the Council of 29 April 2004 on the enforcement of intellectual property rights [2004] OJ L157/45; Recital 11 of the Directive 96/9/EC of the European Parliament and of the Council of 11 March 1996 on the legal protection of databases (1996) OJ L77/20; Recital 4 of the Directive 2001/29/EC of the European Parliament and of the Council of 22 May 2001 on the harmonisation of certain aspects of copyright and related rights in the information society (2001) OJ L167/10, the theory recognizes that IP rights can also be conceived as incentives to diffuse innovation (also known as the prospect theory, see Edmund Kitch, 'The Nature and the Function of the Patent System' (1977) 20 Journal of Law \& Economics 265; Daniel F Spulber, 'How Patents Provide the Foundation of the Market for Inventions' (2015) 11 Journal of Competition Law \& Economics 271). For a review of the CJEU case-law: Martin Husovec, 'Essence of Intellectual Property Rights under Art 17(2) of the EU Charter' (2019) German Law Journal - forthcoming.

${ }^{13}$ See Machlup F and Penrose E, 'The Patent Controversy in the Nineteenth Century' (1950) 10 The Journal of Economic History 1; Eric Schiff, Industrialization Without National Patents: The Netherlands, 1869-1912; Switzerland, 1850-1907 (Princeton University Press, 1971).

14 This phrase was used recently by Advocate General Szpunar when outlining a conflict between neighboring rights of phonogram producers and freedom of artistic expression (see CJEU, C-469/17, Funke Medien [2019], Opinion of Advocate General Szpunar, para 5). 
debate. ${ }^{15}$ Contrary to intuition, therefore, they can become quite expensive innovation policy tool.

In addition, at least in Europe, much of the policy-experimentation in the area is shifting to the supranational level. New IP rights are increasingly proposed directly for the entire European Union without their pre-testing at the national level. In recent years, calls for new Union-wide IP rights seem to be only intensifying. Press-publishers are asking for some rights of their own over press publications. ${ }^{16}$ The organizers of sport events are asking

${ }^{15}$ See on this point in the US context: Mark Lemley, 'Faith-Based Intellectual Property' (2015) 62 UCLA L. Rev. 1328.

${ }^{16}$ European Commission, Proposal for a Directive of the European Parliament and of the Council on Copyright in the Digital Single Market, 14 September 2016, COM(2016) 593 final, Article 11; For scholarship on this proposal, see Lionel Bently and Martin Kretschmer, 'Strengthening the Position of Press Publishers and Authors and Performers in the Copyright Directive' (2017), available at $<$ http://www.europarl.europa.eu/RegData/etudes/STUD/2017/596810/IPOL_STU(2017)596810_EN.pdf>

(accessed 11.5.2019); Richard Danbury, 'Is an EU publishers' right a good idea? Final report on the AHRC project: Evaluating potential legal responses to threats to the production of news in a digital era' (2016) https:/www.cipil.law.cam.ac.uk/sites/www.law.cam.ac.uk/files/images/www.cipil.law.cam.ac.uk/documents/ copyright_and_news/danbury_publishers_right_report.pdf (accessed 11.5.2019); Alexander Peukert, 'An EU Related Right for Press Publishers Concerning Digital Uses. A Legal Analysis' (2016) 22 Research Paper of the Faculty of Law, Goethe University Frankfurt am Main, available at $<$ https://papers.ssrn.com/sol3/papers.cfm?abstract_id=2888040> (accessed 11.5.2019); Mireille van Eechoud, 'A publisher's intellectual property right: Implications for freedom of expression, authors and open content $\begin{array}{llll}\text { policies' (2017), } & \text { available }\end{array}$ $<$ https://www.ivir.nl/publicaties/download/OFE_Implications_of_publishers_right.pdf $>$ (accessed 11.5.2019); Raquel Xalabarder, 'Press publisher rights in the proposed Directive on Copyright in the Digital Single Market' (2017) 39(10) European Intellectual Property Review, pp.607-622; Christophe Geiger, Oleksandr Bulayenko and Giancarlo Frosio, 'Opinion of the CEIPI on the European Commission's copyright reform proposal, with 
for rights to their events. ${ }^{17}$ The automobile-manufacturers are asking for a data producers' right covering data resulting from their collection efforts. ${ }^{18}$ These proposed rights are not the result of a domestic experimentation but rather examples of direct Union experimentation. Although, publishers' rights have a precedent in Germany and Spain, they are new in these

a focus on the introduction of neighbouring rights for press publishers in EU law' (2016) available at $<$ http://www.ceipi.edu/fileadmin/upload/DUN/CEIPI/Documents/CEIPI_Opinion_on_the_introduction_of_n eighbouring_rights_for_press_publishers_in_EU_final.pdf $>$ (accessed 11.5.2019);

${ }^{17}$ See Art 12a of the Amendments adopted by the European Parliament on 12 September 2018 on the proposal for a directive of the European Parliament and of the Council on copyright in the Digital Single Market COM (2016) 0593. For scholarship, see Ben Van Rompuy and Thomas Margoni, 'Study on Sports Organisers' Rights in the European Union' (2014) available at $<$ https://ssrn.com/abstract=2455313>; Thomas Margoni, 'The protection of sports events in the EU: Property, intellectual property, unfair competition and special forms of protection' (2016) 47(4) International Review of Intellectual Property and Competition Law 386.

${ }^{18}$ European Commission, 'Building A European Data Economy: Communication from the Commission to the European Parliament, the Council, the European Economic and Social Committee and the Committee of the Regions' COM (2017) 9 final, p. 13; For the scholarship, see Bernt P. Hugenholtz, 'Against "Data Property"” (2018) 3 Kritika: Essays on Intellectual Property, Chapter 3, 48-71; Bernt P. Hugenholtz, 'Something Completely Different: Europe's Sui Generis Database Right' in Susy Frankel and Daniel Gervais (eds.), The Internet and the Emerging Importance of New Forms of Intellectual Property (2016), p. 205-222; Thomas Hoeren, 'Big Data and the Ownership in Data: Recent Developments in Europe' (2014) European Intellectual Property Review pp. 751-754; Herbert Zech, 'A Legal Framework for a Data Economy in the European Digital Single Market: Rights to Use Data' (2016) 11 Journal of Intellectual Property Law \& Practice, 460; In Japan, a Toyota-led policy initiative materialized in a limited protection of data by means of unfair competition law, see Ministry of Economy, Trade and Industry, 'Cabinet Decision on the Bill for the Act of Partial Revision of the Unfair Competition Prevention Act, etc.' (2018) available at $<$ http://www.meti.go.jp/english/press/2018/0227_003.html> (accessed 11.5.2019) (according to new rules, acquisition, use, and disclosure of 'technical or business information' which do not qualify as trade secrets are protected by some remedies as long as the requirements regarding information management are satisfied). 
countries and national examples are not considered success stories. ${ }^{19}$ Special sports organizers' rights are generally absent in the EU. ${ }^{20}$ The data producers' right is also nonexistent across the EU. These developments change the dynamics of the European project. Unlike in the past, when legislation at the European level was predominantly meant to approximate the existing laws within the Member States, today, the innovation toolkit is directly coming top-down from the Union itself.

Is that a good outcome? How does it affect the Union's flexibility to make good policy? Do we have to accept that these rights are here to stay once they are incorporated into legislation, or can they be repealed? And if so, how quickly can legislators act in case these rights are promised for decades? What is the maneuvering space left by supra-national human rights safe-guards? These are all important questions of today.

We do not have to go too far for real-world examples to illustrate these points. The Database Directive was enacted in 1996 in a climate of growing technological progress in the area of computation and data processing. ${ }^{21}$ The European legislator was worried about the 'very great imbalance in the level of investment in the database sector both as between the Member States and between the Community and the world's largest database-producing

\footnotetext{
${ }^{19}$ See footnote 15 for the overview of the debate.

${ }^{20}$ Ben Van Rompuy and Thomas Margoni, ‘Study on Sports Organisers' Rights in the European Union’ (2014) 178. Available at $<$ https://ssrn.com/abstract=2455313 $>$ (accessed 11.5.2019).

${ }^{21}$ Directive 96/9/EC of the European Parliament and of the Council of 11 March 1996 on the legal protection of databases (1996) OJ L 77/20.
} 
third countries' ${ }^{22}$ In this climate, a new IP right was born - a sui generis database right. ${ }^{23}$ The legislator quite unusually articulated its strongly held beliefs in the preamble of the new legislation, where it said that 'an investment in modern information storage and processing systems will not take place within the Community unless a stable and uniform legal protection regime is introduced for the protection of the rights of makers of databases' ${ }^{24}$

After two decades of having this legislation on the ground we can say that the Directive does not exactly constitute a success story. Although data-related issues are at the very center of upcoming technologies like artificial intelligence, little evidence exists that insufficient data creation is a problem of the day. ${ }^{25}$ In order to assure exclusivity, market players tend to prefer technical and contractual restraints to the exclusive rights. ${ }^{26}$ The first and second evaluation of the Database Directive noted the lack of evidence of any clear benefits. ${ }^{27}$ As explained by the executive summary of the second official evaluation report from 2018, 'the

\footnotetext{
${ }^{22}$ Recital 11 of Directive 96/9/EC.
}

${ }^{23}$ For the overview of scholarship, see Annex 7 of the Study to Support the Evaluation of the Database Directive, available at $<$ https://ec.europa.eu/digital-single-market/en/news/study-support-evaluation-databasedirective $>$ (accessed 11.5.2019).

${ }^{24}$ Recital 12 of the Directive 96/9/EC.

25 Josef Drexl, 'Designing Competitive Markets for Industrial Data - Between Propertisation and Access' (2017) 8 Journal of Intellectual Property, Information Technology and Electronic Commerce Law 257, 273274.

${ }^{26}$ Open Data Institute, 'The role of data in AI business models' (2018) (noting a trend towards open algorithms and closed data), available at https://theodi.org/article/the-role-of-data-in-ai-business-models/ (accessed 11.5.2019); See also Matěj Myška and Jakub Harašta, 'Less is More? Protecting Databases in the EU after Ryanair' (2016) 10(2) Masaryk University Journal of Law and Technology 170.

${ }^{27}$ EU Commission Services - DG Internal Market, First Evaluation of the Directive 96/9/EC on the Legal Protection of Databases (2005). 
sui generis right continues to have no proven impact on the overall production of databases in Europe, nor on the competitiveness of the EU database industry (emphasis added). ${ }^{28}$ Despite this, after the second evaluation, it was concluded that no action is needed because although the Directive did not bring any substantial provable benefits, it did not harm the industries either. ${ }^{29}$ Therefore, according to the conclusions, there is no need to change the laws. This explanation might seem ridiculous at first sight. After all, the Directive is meant to attract benefits which are a measure of its success. The policies are not measured by lack of harm, but by how the newly generated benefits offset their costs. ${ }^{30}$

The central benefit of the Directive that is now being presented instead is the following: '[the Directive] restricts regulatory fragmentation that could be detrimental to the Digital Single Market' ${ }^{31}$ In other words, for the European (Digital) Single Market there can be a value in being united, even if it is behind a wrong solution. This inertia is a result of a

${ }^{28}$ Commission Staff Working Document: Executive Summary of the Evaluation of Directive 96/9/EC on the legal protection of databases $\operatorname{SWD}(2018) 146$ final, (p. 3 - emphasis mine) available at $<\mathrm{http}$ //data.consilium.europa.eu/doc/document/ST-8467-2018-INIT/en/pdf $>$ (accessed 11.5.2019); In the first evaluation, the European Commission summarized this as follows: 'Empirical data underlying this evaluation show that its economic impact is unproven. In addition, no empirical data that proves that its introduction has stimulated significant growth in the production of EU databases could be submitted so far' (see footnote 26, p. 26).

${ }^{29}$ See p. 6 (see footnote 27).

${ }^{30}$ In the first evaluation, the European Commission notes that: 'The arguments for partial withdrawal would largely be based on a strict application of the "better regulation" principles. These principles would probably suggest that the "sui generis" right be withdrawn as it has revealed itself to be an instrument that is ineffective at encouraging growth in the European database industry and, due to its largely untested legal concepts, given rise to significant litigation in national and European courts.' (see footnote 26, p. 26)

${ }^{31}$ See p. 4, footnote 27. 
broader European set-up, where European sharing of solutions, even if not useful ones, is sometimes valued over their disparity. As I will argue, it is a primary reason why accepting - by means of Directives - any new intellectual property rights on the European level before they are properly tested nationally, showing clear benefits that offset their costs, can lock-in the European Union into a set of inefficient policies they cannot easily get rid of.

The Database Directive shows an important weakness of European law-making in this space. If the European legislator decides to intervene and create a new set of IP rights in order to stimulate investment in innovative activities, then effectively abolishing any such rights requires not only removing the European legal basis, but also 'cleaning up' on the national level. Unless the European legislator intervenes by (1) repealing the EU law, and (2) pre-empting now entirely domestic left-over solutions, it causes chaos and fragmentation. Unless the Member States decide to repeal them too, the domestic implementations of a formerly valid directive would remain in place. Moreover, they can now differ across the Member States, including ones which previously had no law on the matter. To avoid this 'forced chaos', the European legislator has to coordinate removal too, which is only possible by means of pre-emption of the national legislations of this kind together with the Unionlevel repeal. ${ }^{32}$ This is because the free movement of goods and services is unlikely to substantially limit the Member States' ability to maintain previously Union-dictated rights.

\footnotetext{
${ }^{32}$ In theory, the EU could oblige a repeal of the implementing legislation, but then provide a room for national solutions. However, this seems entirely contradictory.
} 
Any removal of the European legislation relaxes the free movement enquiry and thus gives the Member States a broader maneuvering space to experiment or not to act. ${ }^{33}$

This is a tricky situation. In particular, because any pre-emption of national solutions demands that the European legislator argues not only that the Database Directive is not useful and hence is not needed, but also that it harms and should be avoided. ${ }^{34}$ However, these are two different policy questions. One could say that they are two different evidentiary thresholds. The usefulness threshold requires showing that the world can continue to deliver innovation without such rights. The harm threshold requires showing that the legislative solution costs more than it benefits. Thus it should be inacceptable even for the Member States to experiment with it in order to preserve the common European innovation frontier. Understandably, this is a much higher burden to bear. This kind of 'negative legislation' to further innovation policy is therefore very unlikely; in particular because European policy-

\footnotetext{
33 For a full argument about why and how the existing policy framework influences the enquiry of free movement see Martin Husovec, 'Intellectual Property Rights and Integration by Conflict: The Past, Present and Future' (2016) 18 Cambridge Yearbook of European Legal Studies 239, 256.

34 The European Commission has committed to a 'better regulation' agenda, which 'is about designing and evaluating EU policies and laws transparently, with evidence, and backed up by the views of citizens and stakeholders.' See < https:/ec.europa.eu/info/law/law-making-process/planning-and-proposing-law/betterregulation-why-and-how_en> (accessed 11.5.2019). Under Junker's Commission, this agenda received further prominence in the work of the 'Task Force on Subsidiarity, Proportionality and "Doing Less More Efficiently', which recently published its recommendations on how the Union could achieve more with less (see Communication from the Commission to the European Parliament, the European Council, the Council, the European Economic and Social Committee and the Committee of Regions, The principles of subsidiarity and proportionality: Strengthening their role in the EU's policymaking COM (2018) 490).
} 
making is subject to proportionality and subsidiarity principles governing its exercise of competence. $^{35}$

Proportionality and subsidiarity require that in the area of shared competence, the Union should act only when it is in a superior position to solve a problem. ${ }^{36}$ Therefore it is intuitive for the European Commission to respond by keeping rights in place unless they result in harm, although their benefits did not materialize. This inertia is a result of the European set-up which requires costly coordination in order to repeal any IP rights grounded in the Directives at the EU level.

The status quo inertia could be partly avoided if the EU legislator would use Regulations $^{37}$ instead of Directives when experimenting with new IP rights. Regulations are directly applicable, and hence there is no need to implement them in the national law. This means that once the EU legislator repeals such instruments, they automatically cease to exist also on the national level. Had the sui generis database right been implemented by means of an EU Regulation, the European Commission could have repealed it much more easily than is currently the case. ${ }^{38}$ This indicates that any experiments with respect to non-traditional IP rights should be carried out directly in the form of EU Regulations. Otherwise the EU creates

\footnotetext{
${ }^{35}$ See Article 5 of the Treaty on European Union OJ C 326. In addition, the criteria for applying these principles are set out in the Protocol (No 2) on the application of the principles of subsidiarity and proportionality annexed to the Treaties - See OJ C 115, p. 206-209.

${ }^{36}$ See footnote 34, p. 2.

37 Treaty on the Functioning of the European Union OJ C 326, Article 288.

${ }^{38}$ To be sure, this would not assure any national pre-emption of rights. However, this is not necessary as the rights would vanish without need of national intervention. The Member States could, of course, institute such rights if they so wish.
} 
a lot of rigidity in the system and essentially prevents an effective repeal of such legislation once it has failed to deliver on its promises.

Although it might sound counter-intuitive that new non-traditional IP rights should be legislated directly while established rights continue to be only partially harmonized, the institutional set-up presented above clearly supports this argument. With respect to traditional IP rights, the situation where the EU legislator would want to radically change them as a whole is extremely improbable - especially given the strong regulatory influence of international public law over traditional IP rights in the area. In fact, an argument can be made that the competence norms of the European Union - Article 114 and 118 TFEU - even require that IP rights which have very little precedent on the national level, and thus pose little if any obstacles to cross-border trade, have to be regulated under a uniform system of protection. $^{39}$

\footnotetext{
${ }^{39}$ See Ana Ramalho, 'Beyond the Cover Story - An Enquiry into the EU Competence to Introduce a Right for Publishers' (2017) 48(1) International Review of Intellectual Property and Competition Law, 71, 74 (arguing that a legislative measure introducing a new form in the EU legal order should be based on Article 118 and Article 114 TFEU). According to the CJEU, 'Article 118 TFEU [...] does not necessarily require the EU legislature to harmonise completely and exhaustively all aspects of intellectual property law' (CJEU, Case C146/13, Kingdom of Spain v European Parliament and Council of the European Union [2015], Judgment of the Court (Grand Chamber) of 5 May 2015, ECLI:EU:C:2015:298, para 48). The Court accepts that 'uniform protection' is assured by various means, including by designating a national law that is to determine it (ibid, paras 39-51), as is the case of the Unitary Patent (see Articles 5(3) and 7 of the Regulation (EU) No 1257/2012 of the European Parliament and of the Council of 17 December 2012 implementing enhanced cooperation in the area of the creation of unitary patent protection OJ L 361).
} 


\section{IP RIGHTS AS FUNDAMENTAL RIGHTS}

The evidentiary threshold discussed above is also important for constitutional admissibility of repeals from the perspective of the EU Charter. I will argue that, when reviewing EU laws, these thresholds are low and the margin available to the legislator is wide. Unlike almost paralyzing evidentiary thresholds that have to be considered by the EU legislator when exercising its competence in order to coordinate repeals, the EU Charter safeguards are much easier to satisfy. At the same time, they pose a different set of challenges, in particular the question of fair compensation. To analyze these situations, we need to make two important distinctions.

Abolishing existing IP rights means interfering with Art 17(2) of the EU Charter. If such an interference is only (1) future-oriented, it concerns only rights to objects which were not created yet. In these cases, the question is essentially whether the legislator may abolish an existing set of rights at all (at any point in time), or whether there is some form of institutional guarantee preventing this. On the other hand, if such an interference is also (2) past-oriented, it concerns also rights to objects that are already protected because they were created under the rules which promised such a reward. The enquiry in this case needs to analyze under what conditions rights can be retroactively abridged, shortened and abolished. It is obviously clear, that for both scenarios, any government needs a good reason to repeal or limit any existing rights. It needs to make a convincing case as to why these rights should be avoided, despite promises being made. I will therefore analyze these two situations from 
the perspective of the EU Charter, drawing also parallels to the case-law concerning the ECHR. ${ }^{40}$

In the European Union, most of the IP rights today are co-designed by national and European legislators with the help of EU Directives and their national implementations (e.g. copyright and national trademarks). ${ }^{41}$ Another set of rights is predominantly designed on the EU level by means of EU Regulations (e.g. unitary EU trademark and EU design systems). ${ }^{42}$ The last set of rights remains mostly in the hands of national legislators because it has been left largely untouched by EU law (e.g. utility models in some countries). The existing practice of European lawmaking is harmonization by means of EU Directives, which leave parts of the law to be determined by the national parliaments. When considering the EU Charter and its applicability, it is crucial to understand which of the situations we are dealing with.

\footnotetext{
40 Although the Convention is not formally part of the EU law (See CJEU, Cases C-217/15 and C-350/15, Criminal proceedings against Massimo Orsi and Luciano Baldetti [2017], Judgment of the Court (Fourth Chamber) of 5 April 2017, ECLI:EU:C:2017:264, para 15), due to Article 52(3) of the EU Charter it has to be taken into account when interpreting the EU Charter (see CJEU, C-469/17, Funke Medien [2019], Opinion of Advocate General Szpunar, para 43).

${ }^{41}$ For instance, Directive (EU) 2015/2436 of the European Parliament and of the Council of 16 December 2015 to approximate the laws of the Member States relating to trade marks OJ L 336/1; Directive 2001/29/EC of the European Parliament and of the Council of 22 May 2001 on the harmonisation of certain aspects of copyright and related rights in the information society OJ L 167/10.

42 See Regulation (EU) 2017/1001 of the European Parliament and of the Council of 14 June 2017 on the European Union trade mark OJ L 154; Regulation (EC) 6/2002 of 12 December 2001 on Community designs OJ EC No L 3.
} 


\subsection{SCOPE}

In the European Union, Article 17(2) of the EU Charter safeguards the protection of intellectual property at the constitutional level. It recognizes that IP rights are a form of property that have to be constitutionally protected. As a fundamental right, the provision applies and constrains whenever the EU Charter does. ${ }^{43}$ By definition, this is the case when EU legal instruments such as Directives or Regulations apply in the area. ${ }^{44}$ Therefore, whenever the European harmonization touches upon IP rights in any manner, Article 17(2) applies to the affected area. However, demarcating this area of applicability is not always simple. Since IP rights are usually a bundle of exclusive rights, one can contemplate redesign that touches only upon its components. For instance, the legislator might single out the distribution right of a copyright holder or the anti-dilution protection for trademark proprietors, for reform. Such choices affect the application of the EU Charter. If the components are purely national, then it is not self-evident that European harmonization that repeals purely national rights will automatically trigger scrutiny by Article 17(2). To clearly delimit the scope of the EU Charter for my enquiry, three issues merit deeper consideration: (1) co-legislation, (2) time-line and (3) the subject matter.

First of all, co-legislation by several parliaments brings some challenges. It is clear that repealing any IP rights, or their components, originating from EU law - be it based on

\footnotetext{
${ }^{43}$ Art 52(1) of the EU Charter.

${ }^{44}$ According to the CJEU, '[s]ituations cannot exist which are covered in that way by European Union law without those fundamental rights being applicable. The applicability of European Union law entails applicability of the fundamental rights guaranteed by the Charter' (CJEU, Case C-617/10, Aklagaren v Hans Akerberg Fransson [2013], Judgment of the Court (Grand Chamber) of 26 February 2013, ECLI:EU:C:2013:105, para 21).
} 
Directives or Regulations, will be subject to Article 17(2) of the EU Charter. So for instance, if the EU legislator would want to repeal the Database Directive, or only some of its sui generis rights, such as the right to prohibit re-utilization, the protection provided by the fundamental right to intellectual property would be activated. However, the situation is less clear for the same changes effected to the domestic IP rights protection framework in the course of European harmonization (e.g. by means of full harmonization).

For instance, when due to the EU copyright reform in the 2000 s, the protection provided to non-original writings (Geschriftenbescherming) under Dutch law was abolished, ${ }^{45}$ this could have triggered a scrutiny through Dutch safeguards, but potentially also under the EU Charter. However, the Charter only applies when implementing EU law. Since national law preceding the legislative change was not enacted for the purpose of implementing EU law, its change due to an act of the EU would, at least at first sight, seem to be outside the scope of the EU Charter. However, one could also argue that legislative changes at the EU level also capture effects of these newly imposed laws on the pre-existing national situation. In other words, where EU law forces Member States to abandon some rights, such effects constitute a direct and anticipated result of their implementation and thus should still be brought within the scope of the Charter's application. From this perspective, Article 17(2) also applies to the question whether an EU instrument sufficiently considered

45 Bernt Hugenholtz, 'Goodbye, Geschriftenbescherming!' at Kluwer Copyright Blog (2013) available at <http://copyrightblog.kluweriplaw.com/2013/03/06/goodbye-geschriftenbescherming/> (accessed 11.5.2019) (In this case, the Dutch parliament amended Article 10 of the Copyright Act. It merely stated that from the date of entry into force, the protection of unoriginal and/or uncreative geschriften will collapse. The legislator did not make the distinction anywhere between existing objects and newly created ones after the entry into force of the amendment. This implies that the protection in fact was not abolished for old works, at least not by the act of the Dutch parliament.) 
the question of pre-existing domestic IP rights that might need to be abolished. After all, the national legislator would have to consider similar questions of national (constitutional) law when acting on its own. Why should we make an exception for EU-led actions?

If the latter argument were to prevail, it becomes clear that the CJEU should be particularly careful as to how it construes protection granted by Article 17(2). As will be explained below, overly-strict levels of scrutiny could paralyze the harmonization process. A good parallel to these considerations is the area of free movement. When applying the principles of free movement, domestic intellectual property rights are considered a form of justification for the maintenance of local idiosyncrasies. ${ }^{46}$ According to settled case-law, such justification has to respect, among other things, the fundamental rights of individuals. Despite these being presented in a form of domestic derogation from the Union principle of free movement, ${ }^{47} \mathrm{CJEU}$ case-law requires that the EU Charter applies. This ensures that what is imposed on the Member states by means of free movement scrutiny is not at the same time incompatible with the fundamental rights of those concerned.

\footnotetext{
46 See for the overview - Martin Husovec, 'Intellectual Property Rights and Integration by Conflict: The Past, Present and Future' (2016) 18 Cambridge Yearbook of European Legal Studies 239.

${ }^{47}$ In ECJ, Case 260/89, Elliniki Radiophonia Tiléorassi AE and Panellinia Omospondia Syllogon Prossopikou v Dimotiki Etairia Pliroforissis and Sotirios Kouvelas and Nicolaos Avdellas and others [1991], Judgment of the Court of 18 June 1991, ECR 1991 I-02925, para 42, CJEU established that discretion of the Member State in case of derogation from Union's law also falls into the scope of its review. And therefore, that national legislation, which invokes derogation, must subsequently also conform to human rights standard of the Convention (paras 44, 45). The decision was confirmed in post-Lisbon setting in CJEU, Case C-617/10, Aklagaren v Hans Akerberg Fransson [2013], Judgment of the Court (Grand Chamber) of 26 February 2013, ECLI:EU:C:2013:105, para $21 \mathrm{ff}$.
} 
In my view, in order to avoid similar conflict in the area of changes to pre-existing IP rights by means of Union legislation, the EU Charter and thereby Article 17(2) should arguably apply when an EU instrument abridges domestic rights. Next to these legalistic considerations, it is also much more efficient in terms of coordination if the CJEU disciplines the EU legislator directly, rather than the objections having to surface through the domestic courts years-later. At the same time, this would force the EU legislator to consider, in the legislative process, the impact of its legislation by thinking about how the envisioned changes could abridge existing rights. A by-product of this approach would be that the CJEU applies the same standard to the changes in Union IP rights. Any coordinated repeal of Union rights, however unlikely institutionally, would be confronted with exactly the same standard of protection. ${ }^{48}$

Another dimension to the applicability of the EU Charter is time. The EU legislator might decide to repeal its own acts, such as the Database Directive. However, doing so means that only the Union dimension of the legislation ceases to exist. Once the only EU instrument in the area is gone, the EU Charter might be inapplicable as the situation after repeal becomes entirely domestic. This threatened to happen after the CJEU repealed the Data Retention Directive ${ }^{49}$ Some of the Member States argued that once the Directive is gone, the CJEU's

${ }^{48}$ In Melloni, the CJEU held that the primacy, unity and effectiveness of European Union law may not be compromised, including by application of the national constitutional law (see CJEU, Case 399/11, Stefano Melloni v Ministerio Fiscal [2013], Judgment of the Court (Grand Chamber), 26 February 2013, Digital Reports, para 60).

${ }^{49}$ See Steve Peers, 'Are national data retention laws within the scope of the Charter?' EU Law Analysis Blog $<\mathrm{http}$ //eulawanalysis.blogspot.com/2014/04/are-national-data-retention-laws-within.html?m=1>; $\quad$ Martin Husovec, 'Opinion of EISi on the scope of applicability of Digital Rights Ireland C-293/12 \& C-594/12', 
case-law setting a high level of protection for the privacy of individuals is no longer binding, since the EU Charter had lost its window of applicability. In the case of the Data Retention Directive this was eventually not a problem because it was still possible for the E-Privacy Directive to provide a basis for the application of CJEU case-law. ${ }^{50}$ However, the problem of the application window remains an issue for other cases. For instance, if the EU were to repeal the Database Directive without also coordinating its national removal, then any constitutional scrutiny that would normally take place under Article 17(2) of the EU Charter, would be barred by the fact that post-repeal, the sui generis right and its treatment by national legislators or courts would be a purely domestic matter. A possible way out of this situation might be to extend the shadow of applicability of the EU Charter even after an EU instrument is repealed. Until this happens, this institutional consideration hovers over any such changes.

Last but not least, Article 17(2) applies only to 'intellectual property' as a type of subject matter. Naturally, any other type of property is still protected by Article 17(1) which grants protection to all 'lawfully acquired possessions'. There is no doubt that copyright, trademarks or patents qualify as intellectual property. However, it is harder to find an objective and all-encompassing criterion for such inclusion. One possibility is to rely on the labelling by the term 'intellectual property' in the legislation. From this perspective, Article 17(2) would have no preconceived notions of the domain, and would provide a full deference to the legislator. Another approach would be to develop an autonomous notion of this term, which would, however, require developing a set of criteria. And although immaterial aspects

\footnotetext{
European Information Society Institute, available at $<$ https://www.eisionline.org/images/projekty/sukromie/OpinionCJEU-EN.pdf> (accessed [11.5.2019]).

${ }^{50}$ Ibid. Directive 2002/58/EC of the European Parliament and of the Council of 12 July 2002 concerning the processing of personal data and the protection of privacy in the electronic communications sector (Directive on privacy and electronic communications) OJ L 201 (2002), p. 37-47.
} 
of these rights and some properties developed in theory like ubiquity, non-rivalry and nonexcludability might offer some clues, it is not clear if these should constitute binding criteria for the subject-matter. The problem of definition can be particularly visible when the CJEU would need to conceptualize national protection mechanisms in the situations discussed above. ${ }^{51}$ However, given the backstop of Article 17(1) protection, this issue seems less salient.

In the context of the ECHR, this question does not arise because the term of 'intellectual property' is not being used. However, the ECtHR had to develop a response to a similar problem when trying to qualify possessions worthy of protection. The approach adopted is to defer to the national legal system when identifying what is to be recognized as a legitimate expectation or an existing property right. ${ }^{52}$

\subsection{INTERFERENCE AND INSTITUTIONAL GUARANTEE}

The case-law of the Court of Justice of the European Union applying Article 17(2) of the EU Charter is growing every year. In the great majority of situations, Article 17(2) is invoked as a protected value in realms of the proportionality analysis. The analysis dictates that the courts have to reconcile the interpretation of IP rights with other fundamental rights, and

\footnotetext{
${ }^{51}$ For more detailed account see: Martin Husovec, 'Essence of Intellectual Property Rights under Art 17(2) of the EU Charter' (2019) German Law Journal - forthcoming

52 Henning Grosse Ruse-Khan, The Protection of Intellectual Property in International Law (OUP 2016), 230; Alexander Peukert, 'The Fundamental Right to (Intellectual) Property and the Discretion of the Legislature' in Christophe Geiger (ed.), Research Handbook on Human Rights and Intellectual Property (Edward Elgar, 2015),138.
} 
consider the reasonableness of the public intervention in this realm. More specifically, it requires that an interference upholds rule of law, pursues a legitimate aim and does so by means that are the least restrictive given the goal(s) pursued.

Intellectual property is a type of lawful possession that is already protected under Article 17(1). According to this provision: '[e]veryone has the right to own, use, dispose of and bequeath his or her lawfully acquired possessions. No one may be deprived of his or her possessions, except in the public interest and in the cases and under the conditions provided for by law, subject to fair compensation being paid in good time for their loss. The use of property may be regulated by law in so far as is necessary for the general interest.' Article 17(2) emphasizes that this also applies to intellectual property. The CJEU indicates interconnection between the two provisions. ${ }^{53}$ According to the Court, ' $[\mathrm{t}]$ here is, however, nothing whatsoever in the wording of that provision or in the Court's case-law to suggest that that right is inviolable and must for that reason be absolutely protected' ${ }^{54}$

${ }^{53}$ CJEU, Case C-277/10, Martin Luksan v Petrus van der Let [2012], Judgment of the Court (Third Chamber), 9 February 2012, Electronic reports, para 68 (summarizing the provision in light of both paragraphs together). ${ }^{54}$ ECJ, Case C-200/96, Metronome Musik GmbHv Music Point Hokamp GmbH [1998], Judgment of the Court of 28 April 1998., ECR I-01953, para 21 ('those principles are not absolute but must be viewed in relation to their social function'); See CJEU, Case C-70/10, Scarlet Extended SA v Société belge des auteurs, compositeurs et éditeurs SCRL (SABAM) [2011], Judgment of the Court (Third Chamber) of 24 November 2011, ECLI:EU:C:2011:771, paras 43; CJEU, Case C-360/10, Belgische Vereniging van Auteurs, Componisten en Uitgevers CVBA (SABAM) v Netlog NV [2012], Judgment of the Court (Third Chamber), 16 February 2012S, ECLI:EU:C:2012:85, para 41. Advocate General Szpunar recently even suggested that using copyright for the purposes not corresponding to its rationales (social function) might be inadmissible as such, see Christophe Geiger and Elena Izyumenko, 'Freedom of expression as an external limitation to copyright law in the EU: The Advocate General of the CJEU shows the way' (2019) European Intellectual Property Review (EIPR) forthcoming. 
In addition to in-built limits of Article 17(1) of the EU Charter, Article 52(1) stipulates that '[a]ny limitation on the exercise of the rights and freedoms recognised by this Charter must be provided for by law and respect the essence of those rights and freedoms'. Any limitations 'may be made only if they are necessary and genuinely meet objectives of general interest recognised by the Union or the need to protect the rights and freedoms of others'. The above provisions create a basic framework for imposing limitations on intellectual property rights.

None of these provisions explicitly address the question of abolishing IP rights. If anything, Article 17(1) hints that any individual expropriation is possible, but only in the public interest, subject to clear legal procedures and 'fair compensation being paid in good time for their loss'. However, this individual protection against expropriation speaks only indirectly about constraints on the option to abolish the title of such possessions in the law. The provision foresees that proprietors are compensated if they are expropriated by the state, but, not whether the underlying entitlements may cease to exist entirely. At the same time, it suggests that such measures are conceivable. Therefore, Article 17 does not explicitly articulate any institutional guarante $e^{55}$ that should constrain a legislator from removing the basis of such lawful possessions for the future. In its language, it merely requires that the legislature sticks to its promises, and if it tries to interfere with them, it has to justify what it does by demonstrating overwhelming public interest, and possibly compensate the affected parties. ${ }^{56}$

\footnotetext{
55 This terms comes from the German constitutional law, but I will use it in my autonomous way in this article. 56 See Martin Husovec, 'Intellectual Property Rights and Integration by Conflict: The Past, Present and Future' (2016) 18 Cambridge Yearbook of European Legal Studies 239.
} 
This paradigm of protection, referred to as a fundamental rule of law by Helfer in his seminal article, ${ }^{57}$ would constitute a logical incorporation of the ECtHR case-law, which has no autonomous program of property rights and only protects those entitlements granted by national systems. As explained by Grosse Ruse-Khan, 'discretion for normative decisions underpinning limits to (intellectual) property shows the highly dependent nature of the right to property' on the choices of the legislator. ${ }^{58}$ Human rights protection by property is therefore 'lacking an independent notion of the substance and scope'. ${ }^{59}$ This means that the content of Article 17(2) could equally be only determined by the legislator's choices and only protect against arbitrary changes of already made choices. If accepted, it means that the provision does not come with a pre-determined program of normative choices of its own. In other words, it does not (institutionally) guarantee any of the legislative choices, but only protects them against a limited set of arbitrary changes once they are legislated. Article 17(2) then does not provide an immunity against legislative change. Therefore, most certainly, in the words of Peukert, '[t]he fundamental right to property does not guarantee today's standard of IP protection'. ${ }^{60}$ However, does it guarantee some bare minimum?

\subsection{EMERGENCE OF AN INSTITUTIONAL GUARANTEE?}

\footnotetext{
${ }^{57}$ Laurence R. Helfer, 'The New Innovation Frontier? Intellectual Property and the European Court of Human Rights' (2008) 49 Harvard International Law Journal 1, 8.

58 Henning Grosse Ruse-Khan, The Protection of Intellectual Property in International Law (OUP 2016). 264. 59 Ibid.

60 Alexander Peukert, 'The Fundamental Right to (Intellectual) Property and the Discretion of the Legislature' in Christophe Geiger (ed.), Research Handbook on Human Rights and Intellectual Property (Edward Elgar, 2015) $142 \mathrm{ff}$.
} 
An institutional guarantee means that the EU legislator would be constrained to recognize and fulfil some minimal objectives when legislating in the area of Article 17(2). In Germany, for instance, the German Constitutional Court recognizes a very limited institutional guarantee underlying the property right. ${ }^{61}$ There is, at least as of now, no comparable concept on the Union level, although reference to the essence of rights in Article 52 might be somewhat related. ${ }^{62}$

Since the EU Charter entered the stage, the reference to 'the essence' in Article 52 was viewed as performing either (1) a complementary role (relative theory) or (2) a substitute role (absolute theory) to the general principle of proportionality. ${ }^{63}$ In the first view, essence only strengthens arguments within proportionality. In the second view, essence is a sub-set of interferences that are always disproportionate. This latter notion could be then understood as providing more hard core limitations on the legislator's choices - one which cannot be outweighed by benefits to the public interest, or by offering compensation. Such 'core

61 Alexander Peukert, Güterzuordnung als Rechtsprinzip (Mohr Siebeck 2008) 702 ff. (an individual is generally enabled to live an autonomous life in the economic sphere independent of public welfare); Peter Badura,

'Zur Lehre von der verfassugsrechtlichen Institutgarantie des Eigentums, betrachtet am Beispiel des "geistigen Eigentums"،, in Festschrift für Theodor Maunz (CH Beck 1981) 14 ff; Peter Badura, 'Privatnützigkeit und Sozialbindung des geistigen Eigentums' in A Ohly and D Klippel (eds), Geistiges Eigentum und Gemeinfreiheit (Mohr Siebeck 2007) 54 ff; For IP case-law, see for instance decisions oft he German Constitutional Court: BVerfG [1971] Schulbuchprivileg 1 BvR 765/66; BVerfG [2016] Metall auf Metall 1 BvR 1585/13.

${ }^{62}$ For more detailed account see: Martin Husovec, 'Essence of Intellectual Property Rights under Art 17(2) of the EU Charter' (2019) German Law Journal - forthcoming.

63 Jonas Christoffersen, 'Human Rights and Balancing: The Principle of Proportionality' in Christophe Geiger (eds.) Research Handbook on Human Rights and Intellectual Property (Edward Elgar 2015), pp. 25-27 (discussing a relative and absolute theories of essence). 
choices' or 'values' would thus always have to be observed and followed by the legislator. Moreover, they would in theory exist for every single fundamental right in the EU Charter. ${ }^{64}$

For years, proportionality has been treated as the main and exclusive instrument to reconcile the conflict. Especially after becoming the main methodology for resolving the conflicts at the ECtHR, it became deeply engraved into European legal thinking about many issues. Any reference to essence in the ECtHR system was understood only as strengthening the arguments within proportionality analysis, or implying higher levels of scrutiny due to the severity of an interference. ${ }^{65}$ At the time of writing, however, the CJEU seems to be at least considering the recognition of essence as a new type of test that is separate from proportionality. In a series of recent decisions - Sky Österreich (2013), ${ }^{66}$ Digital Rights Ireland (2014), ${ }^{67}$ and most importantly, Schrems $(2015)^{68}$ - the Court seems to analytically

\footnotetext{
${ }^{64}$ For more detailed account see: Martin Husovec, 'Essence of Intellectual Property Rights under Art 17(2) of the EU Charter' (2019) German Law Journal - forthcoming.

${ }^{65}$ For an in-depth study, see Eckart Klein, Wesensgehalt von Menschenrechten (Delbrück 2005).

${ }^{66}$ CJEU, Case C-283/11, Sky Österreich GmbH v. Österreichischer Rundfunk [2013], Judgment of the Court (Grand Chamber) of 22 January 2013, ECLI:EU:C:2013:28, para 48 ff.

67 CJEU, Case C-293/12, Digital Rights Ireland Ltd v Minister for Communications, Marine and Natural Resources and Others and Kärntner Landesregierung and Others [2014], Judgment of the Court (Grand Chamber) of 8 April 2014, ECLI:EU:C:2014:238, paras 39, 45 ff.

${ }^{68}$ CJEU, Case C-362/14, Maximillian Schrems v Data Protection Commissioner [2015], Judgment of the Court (Grand Chamber) of 6 October 2015, ECLI:EU:C:2015:650, para $94 \mathrm{ff}$.
} 
distinguish core interferences, ${ }^{69}$ and other ordinary interferences that are subject to the proportionality exercise. ${ }^{70}$ In the literature, Brkan and Ojanen argue in favor of this shift. ${ }^{71}$

The rhetoric about essence of a right to intellectual property is not without a precedent. In the early case-law concerning free movement, the CJEU often discussed the "very subjectmatter' or 'substance' of exclusive rights. For instance, in Volvo, ${ }^{72}$ the CJEU emphasized that removing the ability of a right holder to prevent third parties from manufacturing and selling or importing products incorporating the design is tantamount to the right holder being 'deprived' of the substance of an exclusive right. Similarly, in Dior, the Court notes that '[1]iterary and artistic works may be the subject of commercial exploitation, whether by way of public performance or by way of the reproduction and marketing of the recordings made of them, and the two essential rights of the author, namely the exclusive right of performance and the exclusive right of reproduction, are not called in question by the rules of the Treaty'. ${ }^{73}$

\footnotetext{
${ }^{69}$ Hans D. Jarass, Charta der Grundrechte der EU, (Beck, 3. Edition, 2016), Article 17, paras 28-29 70 Ibid.

71 Tuomas Ojanen, 'Making the Essence of Fundamental Rights Real: The Court of Justice of the European Union Clarifies the Structure of Fundamental Rights under the Charter: ECJ 6 October 2015, Case C-362/14, Maximillian Schrems v Data Protection Commissioner' (2016) 12(2) European Constitutional Law Review, 318; Maja Brkan, 'The concept of essence of fundamental rights in the EU legal order: Peeling the onion to its core' (2018) 2 European Constitutional Law Review, pp. 332-368.

72 ECJ, Case 238/87, AB Volvo v Erik Veng (UK) Ltd. [1988], Judgment of the Court of 5 October 1988, ECR 06211 , para 8.

73 ECJ, Case C-337/95, Parfums Christian Dior SA and Parfums Christian Dior BV v Evora BV. [1997], Judgment of the Court of 4 November 1997, ECR I-06013, para 56 (emphasis mine; here the decision is referencing the Metronome decision).
} 
This case-law emphasizing substance of IP rights was arguably developed in order to identify the crucial features of the legislative choices behind such rights. This was particularly important in the context of free movement, where the CJEU wanted to draw a boundary between permissible and impermissible obstacles to cross-border trade. ${ }^{74}$ However, in the recent years, the CJEU started referring to 'essence' also in the context of its discussion of fundamental rights, including in the context of Article 17(2).

In Coty Germany, AG Cruz Villalón argued that 'it is clear that the essence of the rights would not be respected if the national legislation at issue resulted in the frustration of the right of any holders of intellectual property rights to obtain protection from the courts. ${ }^{95}$ In the decision, the Court mentions essence only in the following passage: ${ }^{76}$

'Article 52(1) of the Charter states, inter alia, that any limitation on the exercise of the rights and freedoms recognised must respect the essence of those rights and freedoms and that it is apparent from the case-law of the Court that a measure which results in serious infringement of a right protected by the Charter is to be regarded as

\footnotetext{
${ }^{74}$ See Martin Husovec, 'Intellectual Property Rights and Integration by Conflict: The Past, Present and Future' (2016) 18 Cambridge Yearbook of European Legal Studies 239.

${ }^{75}$ CJEU, Case C-580/13, Coty Germany GmbH v Stadtsparkasse Magdeburg [2015] Opinion of the Advocate General Cruz Villalon, para 39.

${ }^{76}$ CJEU, Case C-580/13, Coty Germany GmbH v Stadtsparkasse Magdeburg [2015], Judgment of the Court (Fourth Chamber) of 16 July 2015, ECLI:EU:C:2015:485, para 35 (emphasis mine); CJEU, Case C-149/17, Bastei Lübbe GmbH \& Co. KG v Michael Strotzer [2018], Judgment of the Court (Third Chamber) of 18 October 2018, para 46 (only mentions the principle from Coty).
} 
not respecting the requirement that such a fair balance be struck between the fundamental rights which must be reconciled.'

Although the CJEU references Scarlet and Sabam as the source of this passage, the referred decisions actually do not mention 'essence', and only discuss the idea of balance of fundamental rights. ${ }^{77}$ Therefore Coty Germany appears as its first place of use, at least in the IP case-law. Following Coty Germany, the idea re-appears in the Mc Fadden decision, where the Court holds that: '[s]ince the two other measures have been rejected by the Court, to [reject the third one] would thus be to deprive the fundamental right to intellectual property of any protection, which would be contrary to the idea of a fair balance' ${ }^{78}$ Recently, Advocate General Szpunar in Pelham summarized existing references to essence in IP caselaw as follows: 'In the judicial review of the application of the current provisions, fundamental rights play a different role: a sort of ultima ratio which cannot justify departing from the wording of the relevant provisions except in cases of gross violation of the essence of a fundamental right. ${ }^{79}$ In Funke Medien, on the other hand, AG Szpunar discusses internal reconciliation of fundamental rights with copyright law by means of exceptions. He notes

\footnotetext{
77 See CJEU, Case C-70/10, Scarlet Extended SA v Société belge des auteurs, compositeurs et éditeurs SCRL (SABAM) [2011], Judgment of the Court (Third Chamber) of 24 November 2011, ECLI:EU:C:2011:771,, paras 48 and 49; CJEU, Case C-360/10, Belgische Vereniging van Auteurs, Componisten en Uitgevers CVBA (SABAM) v Netlog NV [2012], Judgment of the Court (Third Chamber), 16 February 2012, ECLI:EU:C:2012:85, paras 46 and 47.

78 CJEU, Case 484/14, Tobias Mc Fadden v Sony Music Entertainment Germany GmbH [2016], Judgment of the Court (Third Chamber) of 15 September 2016, ECLI:EU:C:2016:689, para 98.

79 CJEU, Case C-476/17, Pelham GmbH, Moses Pelham, Martin Haas v Ralf Hütter, Florian SchneiderEsleben [2018], Opinion of the Advocate General Szpunar, para 98 (emphasis added).
} 
that these exceptions achieve such reconciliation 'without at the same time depriving authors of the substance of their rights, namely respect for the relationship linking them to their works and the possibility of exploiting those works economically. ${ }^{90}$

As can be seen, the use of essence in the IP opinions and judgements so far does not seem to go beyond a mere suggestion that interference with the crucial substance of a right equals to a serious infringement of such right. ${ }^{81}$ This is in contrast with the idea of essence as a hard core, an institutional guarantee, which could result from the case-law that distinguishes essence from proportionality. The goal of such an institutional guarantee would be to demarcate violations of fundamental rights for which we as a society should not accept any justifications. Since violations of such core would be always disproportionate, they delineate what outcomes cannot be changed under any circumstances. To an extent, from the legislator's perspective, they would constitute red lines which cannot be overridden by democratically elected parliaments in their ordinary course of business. It could be understood as the choices that the legislator cannot legislate away. Naturally, this is a very severe impediment on democracy and should be taken with great caution. For fundamental rights embodied in the EU Charter, like 'effective remedy' or 'human dignity', it can act as a powerful tool against misuse, however, for other positions protected by fundamental rights, it can be a very slippery slope.

\footnotetext{
${ }^{80}$ CJEU, C-469/17, Funke Medien [2019], Opinion of Advocate General Szpunar, para 38 (emphasis added).

${ }^{81}$ For more see: Martin Husovec, 'Essence of Intellectual Property Rights under Art 17(2) of the EU Charter' (2019) German Law Journal-forthcoming.
} 
Until now, the CJEU case-law emphasizes the essence of these legislative choices, and not some constitutional 'program' of minimal obligations. ${ }^{82}$ It is these legislative choices, which are protected by Article 17(2) of the EU Charter, in terms of essence, substance or specific subject matter. It cannot be ruled out that the CJEU will develop such a concept in the near future, with reference to common 'constitutional traditions' of the Member States an analysis that is beyond this contribution. ${ }^{83}$

\section{REPEALING IP RIGHTS}

Any repeal can be future-oriented and past-oriented. To illustrate this, consider a situation in which the EU legislator decides to create a right for press publishers which last 20 years, by means of an EU Regulation. Suppose that after 5 years, the legislator realizes that this right did not help but rather hurt the media landscape. It decides to scrap the law. Since the rights were initially promised for two decades, at the time of changes, some publishers still hold rights that will expire in 20 years. This prompts the following two questions from the perspective of Article 17(2). First, (1) may the EU legislator abolish such exclusive IP rights at all? And if yes, (2) may it abolish them only once all the promises expire, or immediately?

82 Even the notion of positive obligations is dependent on the legislative choices, see Martin Husovec, 'Intellectual Property Rights and Integration by Conflict: The Past, Present and Future' (2016) 18 Cambridge Yearbook of European Legal Studies 239, $261 \mathrm{ff}$. Helfer refers to this viewpoint as enforcement paradigm, see Laurence R. Helfer, 'The New Innovation Frontier? Intellectual Property and the European Court of Human Rights’ (2008) 49 Harvard International Law Journal 1, 40.

${ }^{83}$ For a more detailed account see: Martin Husovec, 'Essence of Intellectual Property Rights under Art 17(2) of the EU Charter' (2019) German Law Journal - forthcoming. 
As was explained earlier, the first question is about whether there is an institutional guarantee behind this right. Once such an institutional guarantee is absent, the second question is in essence a typical proportionality enquiry. Any future-oriented repeals can only interfere with an institutional guarantee (if it exists). From the mere perspective of the proportionality analysis, future-oriented repeals are unproblematic, perhaps with the exception of a transitory period. ${ }^{84}$ This is because once rights are abolished only for the future, no existing rights were being interfered with. ${ }^{85}$ Changing the innovation toolkit after the promises have already expired does not require balancing but only legitimate democratic grounds for a change. If the institutional guarantee is present in some form, the exercise of the will of people is correspondingly circumscribed by constitutional norms.

However, the legislator may need to act quickly. IP rights are often granted for decades, sometimes they even extend over centuries. Future-oriented repeals might be simply too slow to respond to the fast-moving realities in the industries, where the legislators try to intervene by means of exclusive rights in order to stimulate innovative activities. If the legislator is allowed to act only after decades of transition, this could prevent any meaningful reform from taking place. Not to mention if the term of protection expands over centuries as

\footnotetext{
${ }^{84}$ Right holders may object to interference with legitimate expectations (based on ECtHR, Anheuser-Busch Inc v Portugal, no. 73049/01, 11th January 2007, 44 EHRR 42) in the course of the transitory period after the repeal, especially if the exclusive rights are granted after a longer time-lag of an initial investment phase.

${ }^{85}$ For future-oriented legislative redesign, see Alexander Peukert, 'The Fundamental Right to (Intellectual) Property and the Discretion of the Legislature' in Christophe Geiger (ed.), Research Handbook on Human Rights and Intellectual Property (Edward Elgar, 2015) $143 \mathrm{ff}$.; According to Helfer, these re-designs are more often retroactive, i.e. applicable to already existing rights, than it is generally assumed, see Laurence R. Helfer, 'The New Innovation Frontier? Intellectual Property and the European Court of Human Rights' (2008) 49 Harvard International Law Journal 1, 47.
} 
would be the case regarding neighboring rights. Therefore past-oriented repeals are almost by definition also the ones that the legislator would want to resort to. Thus, any meaningful changes to the innovation policy toolkit need to be as fast as the environment which they are meant to address. The shortening or abridgement of existing rights is bound to happen if this course of action is adopted. However, in such cases, the proportionality analysis becomes the limiting factor determining the scope of the EU legislator's actions.

As was already mentioned, Article 17(1) postulates that the deprivation of proprietary interests is possible only if it can be said to constitute a proportionate way of pursuing the public interest. It is required that 'fair compensation [is] being paid in good time for their loss'. Although this principle is not reiterated for intellectual property rights, relying on systematic interpretation, it is clear that these safe-guards equally apply. ${ }^{86}$ The outcome is that it might be constitutionally permissible to abolish rights with immediate effects, however, doing so triggers higher safeguards, in particular it entails (1) a specific evidentiary burden, and requires (2) fair compensation to be paid to the affected parties. Given the nature of IP rights, this is just where the problem starts for our hypothetical EU legislator.

\subsection{EVIDENCE OF PUBLIC INTEREST}

First of all, what evidentiary standard is to be borne by the legislator? The thresholds might differ when engaging only in future-oriented, as opposed to past-oriented repeals. As for the former, it seems sufficient for the EU legislator to argue that the legislation is not any more useful. After all, provided that an institutional guarantee does not exist or is not triggered,

\footnotetext{
86 Christophe Geiger, 'Reconceptualizing the Constitutional Dimension of Intellectual Property' in Paul Torremans (ed), Intellectual Property and Human Rights (Kluwer Law International, 2015), p 115.
} 
the impact on interests protected by Article 17(2) is not present. ${ }^{87}$ As for the latter, namely repeals that also touch upon existing rights, the burden might differ.

At the ECtHR, the evidentiary threshold, however, is still low to demonstrate the public interest. As noted by the ECtHR in James $v U K:$ ' $[\mathrm{t}]$ he taking of property in pursuance of a policy calculated to enhance social justice within the community can properly be described as being "in the public interest". In particular, the fairness of a system of law governing the contractual or property rights of private parties is a matter of public concern and therefore legislative measures intended to bring about such fairness are capable of being "in the public interest", even if they involve the compulsory transfer of property from one individual to another.' ${ }^{88}$ In Pincova and Pinc v Czech Republic, ECtHR restated this case-law as follows:

The Court, finding it natural that the margin of appreciation available to the legislature in implementing social and economic policies should be a wide one, will respect the legislature's judgment as to what is 'in the public interest' unless that judgment be manifestly without reasonable foundation. ${ }^{89}$

\footnotetext{
${ }^{87}$ Alexander Peukert, 'The Fundamental Right to (Intellectual) Property and the Discretion of the Legislature' in Christophe Geiger (ed.), Research Handbook on Human Rights and Intellectual Property (Edward Elgar, 2015) $143 \mathrm{ff}$. (noting that in the German constitutional practice '[s] uch an adjustment is constitutional already if the legislature can show objective reasons for its new policy').

${ }^{88}$ ECtHR, James and ors v United Kingdom, no. 8793/79, 21 February 1986, [1986] ECHR 2, [1986] 8 EHRR 123, para 49 .

${ }^{89}$ ECtHR, Pincova and Pinc v Czech Republic, no. 36548/97, 5 November 2002, para 48.
} 
The states thus enjoy a wide margin of appreciation when considering whether community interests outweigh individual ones. ${ }^{90}$ As recently argued by Advocate General Szpunar in the Pelham case, citing ECtHR case-law, ${ }^{91}$ '[the] balancing exercise must, in a democratic society, be undertaken first of all by the legislature, which embodies the general interest. The legislature enjoys a broad margin of discretion in that regard.' 92 If accepted by the Court, it implies that the CJEU would require an equally low evidentiary threshold as the ECtHR. ${ }^{93}$

\subsection{OBLIGATION TO COMPENSATE}

The second issue concerns fair compensation. Because any full repeal of IP rights would most certainly go beyond control of use and qualify as a 'deprivation' of property, Article 17 would require fair compensation. However, if only one right from a bundle of exclusive rights were to be abolished, a different standard could apply. Depending on how the CJEU

${ }^{90}$ David Harris, Michael O'Boyle, Ed Bates, and Carla Buckley, Law of the European Convention on Human Rights (OUP, 2009, 2nd Edition), p. 667; ECtHR, Sporrong and Lonnroth v Sweden, no. 7151/75, 23 September 1982, 5 EHRR 35, para 69.

${ }^{91}$ Ashby Donald and Others v. France, app. nr. 36769/08 (2013), para 40.

92 CJEU, Case C-476/17, Pelham GmbH, Moses Pelham, Martin Haas v Ralf Hütter, Florian SchneiderEsleben [2018], Opinion of the Advocate General Szpunar, para 94.

93 Similar considerations of the legislator were seen sufficient in Case C-44/79, Liselotte Hauer v Land Rheinland-Pfalz [1979], Judgment of the Court of 13 December 1979, ECR 03727, which obviously pre-dates the EU Charter. In this case, the Court engaged with the public interest analysis and emphasized, when confronting the limitations imposed by EU law on property owners, that: 'In that regard it should also be noted that the Community rules do not impair the substance of fundamental rights.' 
would conceptualize this, such redesign would not have to be interpreted as a 'deprivation'. ${ }^{94}$ For instance, when the Database Directive abridged some national copyright laws which operated with a lower originality threshold for databases, arguably, the sui generis protection could have been interpreted as a substitute mechanism. Even if the situation would be interpreted as a deprivation of property of some right holders, the newly created layer of protection could be seen as a form of fair compensation.

Arguably, compensation may include not only monetary, but also alternative mechanisms of protection. The problem with any compensatory scheme would be how to design it in order to avoid being too costly and over-compensatory on aggregate. If the EU legislator would decide to scrap some IP rights, probably the constituency of actual beneficiaries is very limited. However, this does not mean that the group of theoretical beneficiaries is equally narrow. IP rights are often applicable in many areas, but only a few of them become commercially valuable and invoked. Creating a compensatory scheme would naturally make all the beneficiaries interested, not only those with valuable rights. Therefore designing a proportionate system of compensation which avoids the pitfalls of overcompensation can be a challenge and generally a costly affair.

For past-oriented repeals, several lessons can be drawn again from the wealth of ECtHR case-law. According to the settled case-law of the ECtHR: 'It follows that the balance mentioned above is generally achieved where the compensation paid to the person whose property has been taken is reasonably related to its "market" value, as determined at

94 C.f. David Harris, Michael O'Boyle, Ed Bates, and Carla Buckley, Law of the European Convention on Human Rights (OUP, 2009, 2nd Edition), p. 667. In the German case-law, a similar idea was expressed by the German Federal Constitutional Court in the decision Bearbeiter-Urheberrechte, 31 BVerfGE 275 (1971), para 28. 
the time of the expropriation'. ${ }^{95}$ However, 'legitimate objectives of 'public interest' may call for less than reimbursement of the full market value' ${ }^{96}$

The ECtHR therefore generally requires market value, but also accepts that in some circumstances, even less than market value can be offered to the affected parties if justified by exceptional circumstances of the public interest. ${ }^{97}$ The states again enjoy again a wide margin of appreciation in designing these compensatory schemes. ${ }^{98}$ The overall goal is to maintain a fair balance between community and individual rights. Therefore, a broad range of solutions should be possible, ranging from monetary compensation upon fulfillment of some criteria to alternative protection schemes. However, the main message is that repealing such rights for already granted rights will be both a costly and organizationally demanding task.

\subsection{ARTICLE 17(2) AND INTEGRATION PROCESS}

Moreover, coming back to the earlier point about the scope of applicability of Article 17(2), this circumscribed view of the safeguards is equally important for the feasibility of the process of European integration. If we were to accept that Article 17(2) applies also to situations where the European harmonization removes local forms of IP protection, then the

\footnotetext{
95 ECtHR, Pincova and Pinc v Czech Republic, no. 36548/97, 5 November 2002, para 53.

${ }^{96}$ Ibid.

${ }^{97}$ ECtHR, James and ors v United Kingdom, no. 8793/79, 21 February 1986, [1986] ECHR 2, [1986] 8 EHRR 123.

${ }^{98}$ David Harris, Michael O'Boyle, Ed Bates, and Carla Buckley, Law of the European Convention on Human Rights (OUP, 2009, 2nd Edition), p. 681.
} 
same thresholds of protection would be applicable to these domestic IP rights. If the requirements for the legislator were to be higher than those derived from the ECtHR caselaw, this could impede the harmonization process. The EU legislator would have to not only take into account the existence of such rights, but potentially think of much more elaborate, lengthy and expensive schemes of transition after their implementation. For instance, consider again the EU copyright reform (fueled by the CJEU case-law) which forced removal of the Dutch protection of non-original writings by the Dutch legislator. If such effects were to require interim compensation, the EU law-making process in the area of intellectual property would be substantially altered. The policy-making would often settle for the least common denominator, the lowest thresholds of protection or broadest scope, just to avoid the above presented considerations. ${ }^{99}$ However, if partial re-design can be seen as a trade-off of the newly harmonized bundle of exclusive rights, the abridgement of rights might remain uncompensated.

\section{CONCLUSIONS}

99 This force is powerful today even without constitutional considerations. For instance, during the trademark reform, Benelux countries were worried about pre-emption of their anti-dilution protection. As a consequence, anti-dilution protection for reputed trademarks was incorporated into the law as a choice in Article 5(2) of Directive 89/104 (see Graeme B. Dinwoodie, 'Dilution as unfair competition: European echoes' in Rochelle C. Dreyfuss and Jane C. Ginsburg (eds) Intellectual Property at the Edge: The Contested Contours of IP (CUP 2014), p. 92). After two decades, when the Directive was re-evaluated and amended in Article 10(2)(c) Directive 2015/2436, the choice was made mandatory for all the Member States. 
Innovation policy should be agile. The current trend within the Union of engaging in experimentation with new untested IP rights is short of valuable feedback from the national level. IP rights are legislated without successful pre-testing. They are thus much more unpredictable in their effects. If experimentation in EU-law making takes the form of Directives, the newly established IP rights become hard to repeal. Not necessarily because of the constitutional constraints, but due to the fact that any European repeal needs to be complemented by a concerted series of domestic repeals in order to be effective. This is naturally very hard, as it requires legislation that pre-empts national solutions. Such legislation comes with a higher evidentiary threshold due to the EU rules on competence. This status quo inertia is one of the institutional reasons why the EU should either resort to experimentation by means of Regulations, or carefully pre-test newly proposed rights at the national level.

Unsurprisingly, Article 17(2) of the EU Charter imposes some limits on repeals of newly established rights too. Unless the CJEU will develop some form of broad institutional guarantee, future-oriented repeals, which only prevent new rights from arising, should be largely possible. However, changes to innovation policy require rapid actions, and thus pastoriented repeals might be necessary in cases when awaiting the expiration of rights is not an option. In these cases, proportionality seems to still remain the main paradigm for resolving the conflict between collective and individual interests. While a partial re-design of rights might avoid compensation, the full repeal of rights will in principle demand it. If the CJEU is to adopt the ECtHR's criteria for expropriation, this would mean a wide margin of appreciation for the EU legislator when formulating the public interests. However, such repeals would entail costs to the state which has to compensate the right holders. In addition, non-negligible practical issues would arise when designing these compensatory schemes. To summarize, the legislature has three choices: (a) to wait until existing IP rights expire, (b) to 
substitute existing IP rights by transforming them to other mechanisms, or (c) to compensate expropriation of existing rights. In either case, undoing legislative choices is costly, especially in a federal system. 